\title{
Traditional Music in Igbo Culture: A Case Study of Idu Cultural Dance of Akpo in Aguata Local Government Area of Anambra State
}

\author{
Okpala, Nkechi H. \\ Department of Music \\ Chukwuemeka Odumegwu Ojukwu University \\ Igbariam, Anambra State, Nigeria. \\ Telephone: +234703196035 \\ E-mail: okpalahn@gmail.com
}

\begin{abstract}
Igbo people are endowed with numerous dance music performances which portray the culture of the people. Traditional music is so much a part of Igbo culture that majority of the people who live in big cities and other places outside their home town organize traditional music ensembles as a mark of identity, to preserve their culture and to serve as a unifying factor that binds them together. This valuable Igbo culture is fast fading away in most communities as the younger generations are losing interest in this music genre. This paper therefore views traditional music as an indispensible part of Igbo culture. It further investigates among other things the history and performance of Idu cultural dance. To achieve this, the researcher employed some information gathering techniques such as oral interviews, fieldwork and review of related literatures. This research work reveals that despite the alarming influences of the western technology on Igbo culture, dance music performance has remained the climax of every cultural and social event in Akpo community. It also suggest that the people be encouraged in their music practices, to achieve this, music scholars should research on the activities
\end{abstract}


of music groups within and outside their communities. This will encourage them to hold fast to their activities knowing that there are people that have interest in them.

Key words: culture, dance, performance, Igbo people, traditional music.

\section{Introduction}

The Igbo people are Igbo speaking people found in the south eastern Nigeria. Agu, (2011) states that:

The Igbo of Nigeria are particularly located at south eastern part of country. They also extend to a part of the south - south and the delta regions of the country. The Igbo, east of river Niger covers Imo, Anambra, Ebonyi, Enugu, and Abia state. These state occupy a land mass of about 29,230.2 square kilometers of Nigeria's total land area of the 356,669 square kilometer. The Igbo tribe is one of the three largest tribes in Nigeria (p. 1).

Igbo are very industrious people. They are mostly farmers and traders, some are craftsmen. Okafor (2013: 135), views Igbo people as a people with great commercial bent and this is why it is not surprising to find Igbo people in every corner of the Nigeria, either as traders, contractors, artisans and civil servants. Apart from being business oriented, Igbo people are great lover of music; music is part of everyday life in any Igbo community. The Igbo are one of the most musically oriented people in Africa (Okafor 2013: 151). They do not just perform music for aesthetic purposes; music is a lifelong activity that serves as a medium for cultural transmission. Their musical activities are associated with every stage of one's development in life. Okpala (2006) states that:

All Igbo society has provided the musical training for their people right from childhood. And the nature, scope, and quality of the training is so efficient that it offers and average Igbo a comprehensive and sound musical knowledge in more than one of the various aspects of Igbo music (p. 3).

Among the various traditional music types practiced in Igbo culture, dance music has been seen as the most captivating. The discussions in this paper are limited to dance music. Dance music is organized in Igbo community as a social event. The organization and performance of dance music vary based on community's orientation and values. In Akpo, every class of individual has a particular dance music that is very peculiar to them. As a result there are many dance music types in the community that accompany social or cultural events, which may fall into any of three types of traditional music in Nigeria as observed by Agu (2000: 82) namely; recreational, occasional and incidental music. 


\title{
Historical Background of Akpo
}

Akpo fondly called Ogaranya bi n'ugwu was the second issue out of the three children of late Nnoebe Dike. He had three children namely; Amesi, Akpo and Acahina. Akpo was given the name Akponnaya because he looked exactly like his father, which was later shortened to Akpo. Akponnaya married two wives - Ezi and Ihite. Ezi was the mother of Agbelu, Uhuala and Umueze while Ihite the second wife gave birth to Ogbo and Amaife. He had one adopted son which was Udo. These represent the six villages in Akpo. Discussing the origin of Akpo Ezenwata (2012) states that:

\begin{abstract}
Akpo as a single autonomous community is made up of six semiautonomous villages namely; Agbelu, Uhuala, Ogbo, Umueze, Amaife and Udo. These six villages enjoy brotherly harmonious relations: agree in all forms of external effort for the security of the town. They have two common fronts as a key bond of union to ensure that the name "Akpo" will ever be defended with the last blood of any Akpo citizen (p.1).
\end{abstract}

Akponnaya was a great warrior and his descendants took after him. They recorded many successes in the wars fought in the past. Their war-like nature is evident in most of their music. This agrees with Okafor (2005: 89) which recounts that when the music of a traditional society is brought to a closer focus, recognition of status, occupation, ceremony, or activity begins to dawn on the listener. The cradle song "Ghara Nwannem' is an example of songs that depict Akpo people as warriors.

\section{Igbo}

Ghara, ghara, ghara

Ghara nwannem

Ghara mgbe Akpo je-eje ogu

Ka m gbutere gi isi

\section{Translation}

stop, stop, stop

stop crying my sister/brother

stop crying when Akpo will go for war

I will get you heads

Akpo is a community with a very rich cultural heritage; this is evident in the feast and festivals they observe. They have two major deities namely; Nkwo and Ezekolo, which are celebrated annually. Every kindred and family have their own inner deities, which they believed were responsible for their successes both in fruitfulness, agriculture, victories in war and many others. These deities were also celebrated by the owners at one time or the other by the owners with suitable music types. There are music types that accompany every feast or festival. This is believed to be responsible for the varieties of music performing groups in the community. Akpo, like any other Igbo community has musical activities for all classes of people; social groups like age 
grade, title groups, palm wine tappers, hunters, carvers, women, men, medians and youths are identified with a particular music type. These according to Okafor (2005: 93) build up the rhythm of life in the communities.

The advent of Christian religion in Akpo brought an end to most of the feasts and festivals they performed in the past leading to total extinction of most musical groups that existed in the past. However, despite the influence of Christian religion, $I d u$ and a few other musical groups are still functional in Akpo. The lyrics of some musical group were substituted with moral/religious texts which helped the groups to survive till date.

\section{Ogbo Village}

Ogbo is the third son of Akpo, and the third largest of the six villages. They are the owners of $I d u$ cultural dance. Membership into the group is restricted to Ogbo people. There are eight kindreds in Ogbo namely; Dimoha, Dimaku, Umuohi, Umuachala, Egbe, Unu-Achi, Dimagbagbeshi and Dimonyegwara. Every titled man is conferred with the title 'dim' during title taking. The village has two major cultural dance groups for the male folk - Ogba-Agu and Idu.

\section{What Is Music?}

The terms music has been defined in various ways by many scholars. Blacking (1973) in Okafor (2005: 270), defines music as a humanly organized sound. Odunuga (2009: 1) views it as the combination of sounds that are pleasant to hearing. Ekwueme (2008: 1) defines it as a phenomenon using the medium of sound which is organized and manipulated into socially accepted and manfully, verbally, ideals, feeling, emotions and event to people.

From the above definitions, one can aptly deduce that music is a product of an organized sound that is pleasing to the ear. Music is so much a part of the background of everyday life that it tends to be taken for granted in contemporary living. Yet, for many people it is a powerful focus for creative energy and one, which stimulates and guides imaginative thinking (Okpala, 2006: 1). Chuma-Udeh (2014) posits that:

Music is the universal language of the soul and the music of oral literature flows from the essence of a people's existence. Here it becomes a way of expression intricately tied to their social, cultural, and to a great extent becomes the determinant of the peaceful coexistence of the society of the people that spawns it (p. 15).

The above assertion by Chuma-Udeh implies that music is part of human existence on earth. This existence comprises and implicates various activities in our environment. The totality is what is loosely defined as culture (Okafor, 2005: 87). Okafor (2004) in 
Okafor (2005: 2) identified three classes of music that exist in Nigeria namely; the traditional, popular and classical. This study is concerned with traditional music.

\section{Traditional/Folk Music}

Agu (1990: 80) defines folk music as the indigenous music of the people which forms an integral part of their way of life. Isaac (2013:56) views it as a communal art which voices the expectations, sentiments, legends, myths, taboos and the history of its people. Okafor (2005) in Agu (2011: 16) states that folk/traditional music springs from the cultural womb and can develop or grow through the years mutating, enlarging, but always maintaining its original genre. Folk music is the indigenous music of a people within a particular culture area. It is a part and parcel of Igbo culture which is orally transmitted from one generation to another. Folk music is performed in the native language of the owners and with local musical instruments within the culture area. Folk music is said to have been originated from folktales.

\section{Traditional Music in Igbo Culture}

Traditional/folk music is an integral part of Igbo culture. Its impact on the life of people cannot be overemphasized. In Igbo culture, music is not just performed for its aesthetic purposes; it is a medium for cultural transmission. Music is an essential part of the Igbo man's life. There are musical activities associated with every stage of development in one's life. Agu (1990) states that:

Among the Igbo, it is said that music serves not only as a medium for entertainment and social relationship, but as an intricate part in the development of the mind, body and soul. It is assumed that the laws of the land are learnt through songs. The history of the tribe is learnt through songs and the accepted behavioral patterns in the society are all assimilated through music and dance (p. 49).

The above assertion explains the reason why folk music has remained in Igbo culture despite the strong influence of western culture especially during the period of western colonization. In Igbo societies, music is performed as a social event as is the case with other African societies; in agreement with this Forchu (2011) and Nketia (1974) observed that, in traditional African societies, music making is generally organized as a social event. 'However this does not preclude individual music making' Nketia (1974:21). Onyeji (2013: 58) posits that African music is not a separate autonomous domain; it is inextricably caught up in a web of domestic social and political activities. This is in conformity with Miller (1972) in Agu (2015: 2) which states that music, like other arts, is not autonomous. He argued that it is always part of a total culture both in time and place. Music is part and parcel of life in Igbo culture.

The roles of folk music in shaping the life of Igbo people are innumerable. It ploughs the mind of the people that make up the society leaving them as law abiding 
citizens. Through folk music the conventional rules of behavior are maintained. This is achieved when right conducts are encouraged through praise and appreciation, and ill behaviors discouraged through caution and ridicule. Breeding citizens with right mind sets go a long way to encourage development.

\section{Dance Music}

Dance music is the most captivating and most widely practiced of all the music genres. Dance music could be viewed in three categories namely; instrumental dance music, vocal dance music and a combination of both- vocal instrumental dance music. Instrumental or vocal parts supply the rhythm which the dancers dance to. In other words, without instrumental or vocal music, dance will be meaningless. Peggy Harper (1970) in Ugolo, (2012) states that, as in all forms of Nigerian dance, the fundamental formal elements of the dance are the close relationship between the rhythmic patterns of the dance and the rhythm of the accompanying music or song. He further noted that:

In many Nigerian societies, there is a very close relationship between dance and music. In fact, in many cultures, the same word is used for both music and dance. Therefore, in Nigeria it could amount to madness to dance without music. This suggests the closeness of dance and music as they feed on one another in their many forms (p.99).

The basic movements of dancers are influenced by the rhythmic structures of music vocal or instrumental that accompanies the dance. Here, rhythm may serve simply as a propelling factor which might stimulate expression or animate performance Nketia (1975:211). It also establishes the dancer's motor beat and the dancer's movement speed. In most dance music ensembles, the signal for dance sequence is given by the player of the master instrument which could be a membrane drum, wooden drum, big metal bell or any other instrument chosen by the ensemble, based on their music type.

Every dancer in an ensemble must know the music too well, be it instrumental, vocal or both. This will enable him/her to respond to signals for change in the dance movements as indicated by the instrumental or vocal part. The dancers are not rigid in their stylized dance performance, Onwuka (2012:6) and Olaniyan (2014:7) agree that in dancing, the dancers combine both spontaneous and rehearsed movements during performance.

\section{Origin and Organsation of $I d u$}

Onwuka (2012:17) observed that, every cultural dance has a traceable source or point from where it started. He goes further to say that it could be sourced by copying and blending of some prevalent dance patterns from another community (culture) or adopting in its entirety, another cultural community. This is what Nzewi, (2007) called musical art borrowing. He asserts that: 


\begin{abstract}
Musical arts borrowing in the indigenous setting bonded individuals and communities/societies, and had prescribed procedures, which implicated vast societal and human issues. It generated human-cultural interests, values and relationships far beyond musical arts matters. Musical arts borrowing as such occur when an organization or group in one community sets out to acquire a favored musical arts style practiced by a group in another community or society (p.139).
\end{abstract}

The knowledge of the historical background of any music ensemble is necessary to understand the performance and the functionality of the group. Music borrowing was practiced in Igbo communities and is still practiced in this age though it is not as significant as it used to be in the past. This affirms Ifionu in Keke and Obiekwe's (2012:308) observation that, there used to be the culture of borrowing music and musical instruments from the neighboring villages and towns in Igbo land which is almost a forgotten culture.

$I d u$ cultural dance was borrowed from Umuomaku town over 50 years ago. The idea of borrowing the dance was initiated by Late Azubuike Okemili, Late Ezechi Ezeno and Late Alaedum Dimnwaeze. After negotiation, the conditions given by the owners of the dance were fulfilled; the teaching and learning period commenced and it lasted for two years. This act established a lasting relationship between not only the villages but the entire Akpo and Umuomaku communities. The music ensemble is presently known as Idu Akpo not Ogbo. This agrees with Nzewi's (2007: 137) submission that any and all music produce in an indigenous culture was by convention the property of the community collective. The history of the origin of $I d u$ here is contrary to the submission by Akas (2014) which states that:

This dance $I d u$ was believed to have been performed by the strongest man in Akpo village in Aguata. This man was declared the strongest man because he was a strong wrestler, a good farmer and a fearless man, on several occasions, it was said that he has fought with spirits unconsciously and defeated them (p. 198)

The establishment of the group was necessary as a result of the quest and desire of the people to have an entertainment music ensemble that will be very outstanding and unique. It was also established to give them (the village) a unique identity, to raise fund for community development and to serve as an agent of unity. Their first performance featured about twenty members. The numerical strength of the group has continued to increase over the years. Idu is made up of varying personalities which are endowed with different creative abilities. The organizational structures of $I d u$ is in line with Onwuka's (2012: 12) assertion that a typical Nigerian traditional or contemporary dance group consist of selected members who are functionaries, expressive artists or attendants. The functionaries of $I d u$ were picked by appointment; this has been the 
practice of the group since inception. They have five posts namely; the Chairman, Assistant Chairman, Secretary, Financial Secretary and Treasurer. The present officials are: chairman - Udejikwa Dimakunne, assistant chairman - John Nwosu, secretary Ernest Dimonyeka, financial secretary - Innocent Dimonyegwara, and treasurer Cyprain umennaike.

Rules and regulation of the group states that:

- Fighting is forbidden among members, the penalties for defaulters are a cock and a hen (oke okpa na nnekwu okuko).

- Absence from meeting without cogent reasons attracts penalty

- No member of the group has the right to teach the music to any other group.

\section{Recruitment of New Members, Training and Rehearsal Periods}

Nketia (1975) views recruitment as any social arrangement that ensures the availability of specialist for established role and position in the society. He goes further to state that:

Since the success of a musical event depends to a large extent on good musical leadership, the recruitment of a musician is something of a prime concern to social groups, especially where performances are based on different participation and role distribution that demand specialization (p. 56).

Recruitment of new members into $I d u$ cultural dance is based on certain criteria namely:

- The potential member must be up to thirty years.

- Must be from Ogbo village.

- Must be initiated into masquerade cult.

- Present four cola nuts, four alligator pepper, one gallon of palm wine and two hundred naira.

Anyone that does not meet up with any of the above requirements is denied the opportunity of being a member of the group, initiation into masquerade cult is necessary because the activities of the group involve two masquerades.

Since inception of the group, the periods for rehearsals have always been at night from $11 \mathrm{pm}$. There are no specific days for rehearsals. They rehearse two or three days before any performance depending on the number of old members available at that time. Members are informed of the performance schedule by the summon signals passed through beating of nne ekwe. The present rehearsal venue is at the residence of Mr. Tony Udohohia. The choice of venue was made based on its centrality and ample space which is sufficient for rehearsals. The compound is also fenced which is an 
advantage to the group. This agrees with Onyekwelu (2012: 6) which outlined the things to consider while choosing dance rehearsal venue as:

1. The centrality of the venue for the convenience of the members.

2. How spacious the venue was for accommodating everybody.

3. Shelter for the members in case of unexpected rainfall.

Training of new members is done during rehearsals. The creative abilities of the members are tested; some are trained as instrumentalist while some are trained as dancers. The new instrumentalists are assigned to instructors who drill them on the playing techniques of the particular instrument(s) they been understudying. The group had never at any time lacked instrumentalists because one or two persons that play a particular instrument must be readily available to play in any of their performances.

\section{Costume and Makeup}

The selection of costume in folk music performance is not a random one. Rather, in doing so, many factors are put into consideration. Costumes are carefully selected to portray the mood of the music and also to transmit the massage of the group to the audience. As a result, not all folk dances require beautifully designed costumes. Some even require the barest minimum of clothing (Agu, 2000: 79).

The above statement by Agu clearly shows that the type of dance determines the type of costumes to be used. Costumes add glamour to dance performances. In dancing, costumes forms part of the movement complex Nii-Yartey (1998: 62). The choice of costume in $I d u$ falls in the category of folk dances that does not require beautifully designed costumes but the barest minimum of clothing. The costume worn by Idu dancers are just shorts and sliced dried goat skin sown together and tied round their waist. The sliced goat skin is also used to make caps. They also make use neck beads and secondary seed rattle on both legs. Each of the dancers has a knife clipped to his waist. Their faces and bodies are decorated with charcoal paste. All these make them look fearful and dreadful to the extent that most people, both male and female run away at the sight of the dancers. 


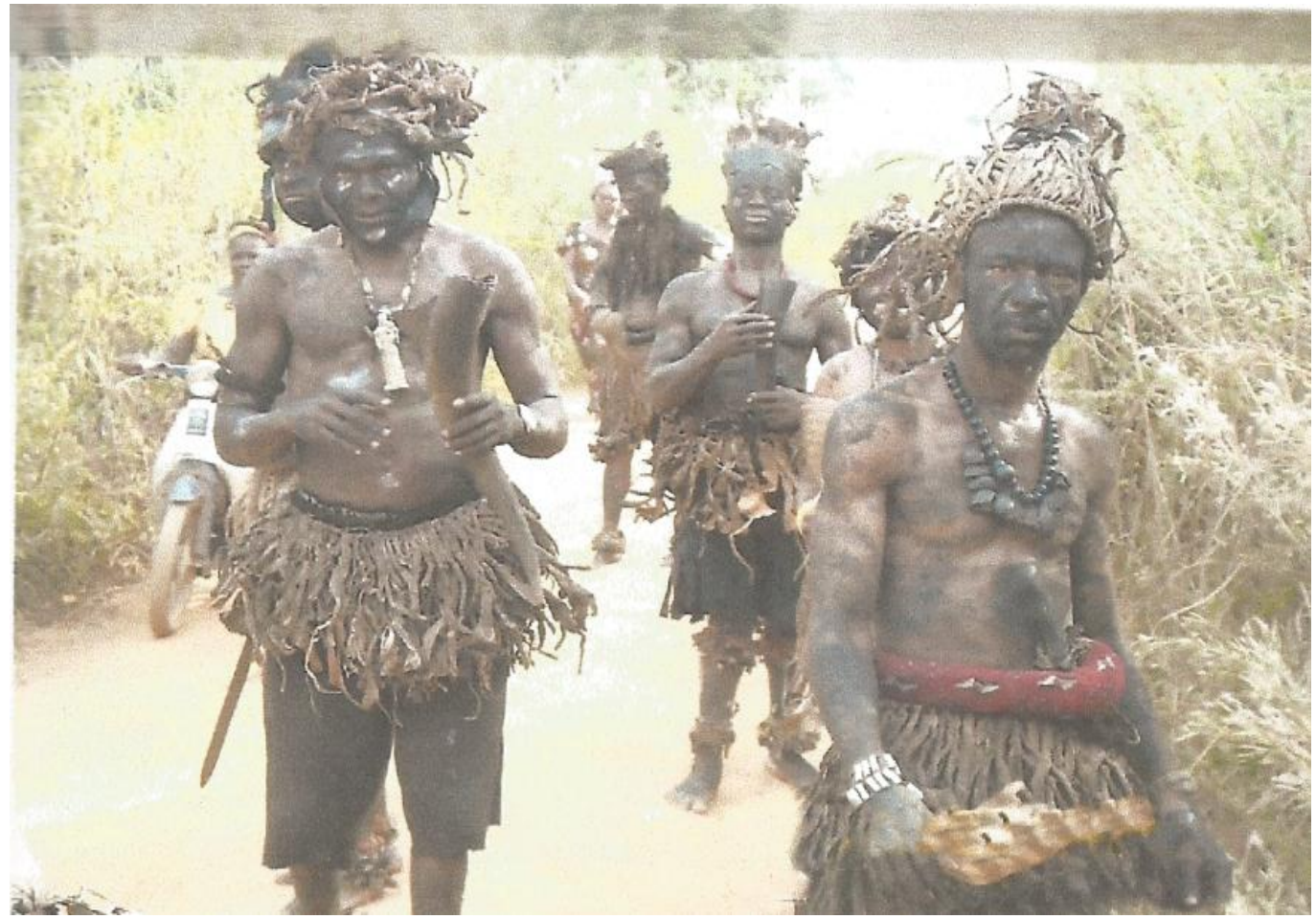

Plate 1: dancers in their costume

Consume is one of the things that make them outstanding. This probably must have contributed to the wrong notion held by some individuals that have made some documentations on the group's musical activities. Akas (2014) states that:

The reason for not allowing women to partake in the dance is that is that it is believed that once they watch the dance they will no longer see their menstrual cycle and any pregnant woman that watches them will give birth to a monkey. Also if a woman mistakenly meets them on the road, she must pass through their left hand side in order to avoid dis-charming their charms (p. 201).

Aka's submission by akas is contrary to what obtains in Idu in respect to their audience participation; women are allowed to watch the performance along with other members of the community. Even when they perform outside the town, the audience includes both sexes. The costumes are locally made by the group. The instrumentalists do not wear costumes. 


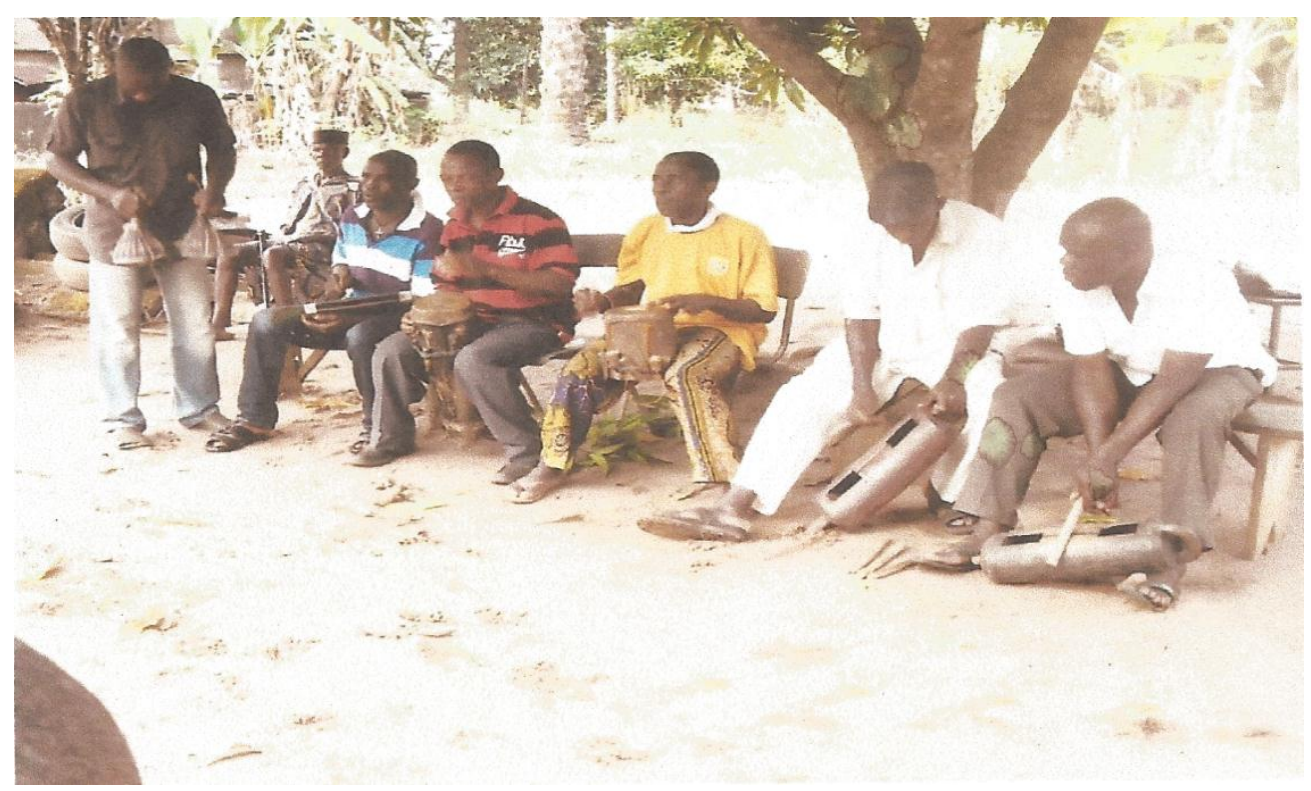

Plate 2: picture showing the instrumentalists

\title{
Instruments of Idu
}

Musical instruments are indispensible in any dance performance. Different performing groups choose the musical instruments that appeal to them based on their orientation and the types of performance. This agrees with Agu's (2000) discussion on instrument which states that:

\begin{abstract}
Musical groups do not simply go a shopping for any musical instrument they fancy. Rather, there is usually a conscious and careful selection of instruments to suit the orientation of each group. Thus the function and utility of the music performed by the group determines the size and composition of the instruments to be used by any group (p. 80).
\end{abstract}

$I d u$ cultural dance is not a mobile group per say but they usually walk some distance into the performance arena. This prompted then to go for those instruments that are not weighty .Because their group emphasizes on rhythm, they made use of rhythmic instruments. Their instruments are predominantly instruments of the idiophone family. The group employed eight local instruments in their dance namely: nne igba (membrane drum), oke igba (membrane drum bigger than nne igba), nne ekwe (wooden drum), oyo (basket rattle), opu (horn), okpokolo (wooden block), oja (end blown flute). These instruments were not constructed by the group; they were bought from the market. 


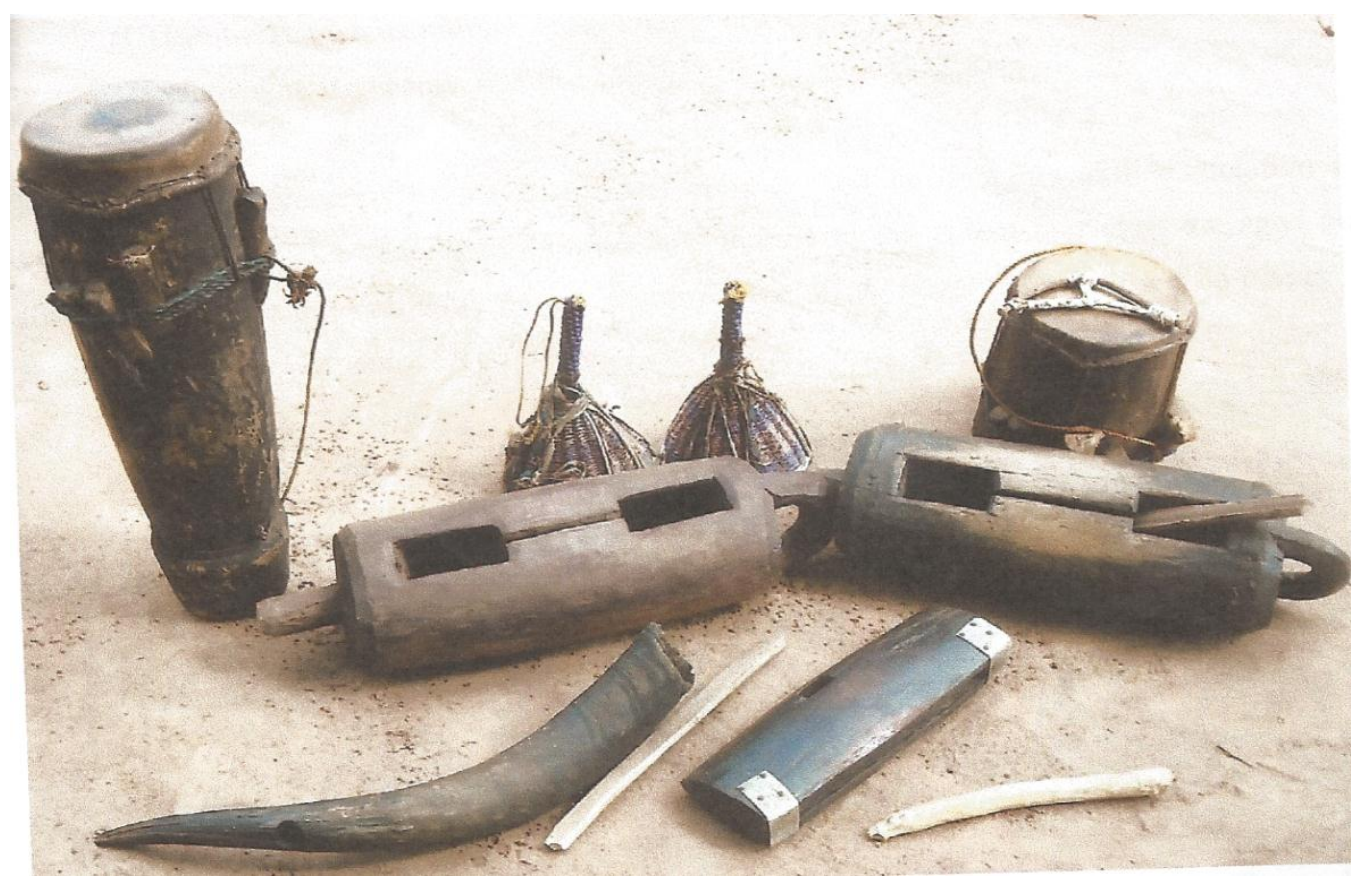

Plate 3: Instruments of $I d u$

\section{Performance Situation of Idu}

$I d u$ cultural dance is an instrumental dance greatly valued by the owners and the spectators. Both the dancers and instrumentalists display high creative abilities during performances this is typical of African music performances. Nzewi (1999) in Onyeji and Onyeji $(2011$, p.20) states that there will always be a definite creative intention, creative design, and structural as well as idiomatic content to validate a music product as a veritable cultural achievement. The dancers require energy as they use what Onwuka (2012:10) referred to as the active human body which includes:

(A) Head (that is, from the neck upwards)

(B) Torso (which includes the shoulders, trunk, hip, buttocks)

(C) Limbs (which comprise of legs, knees, ankles, feet and toes. Others are the arms, elbows, wrists, hands and fingers)

The rhythmic movements of the dance are complex and needs highly skilled, creative and energetic dancers. The dancers of $I d u$ are well trained to the extent that even the aged ones among them perform excellently during the performances. They never get exhausted no matter the length of time a performance lasts. 


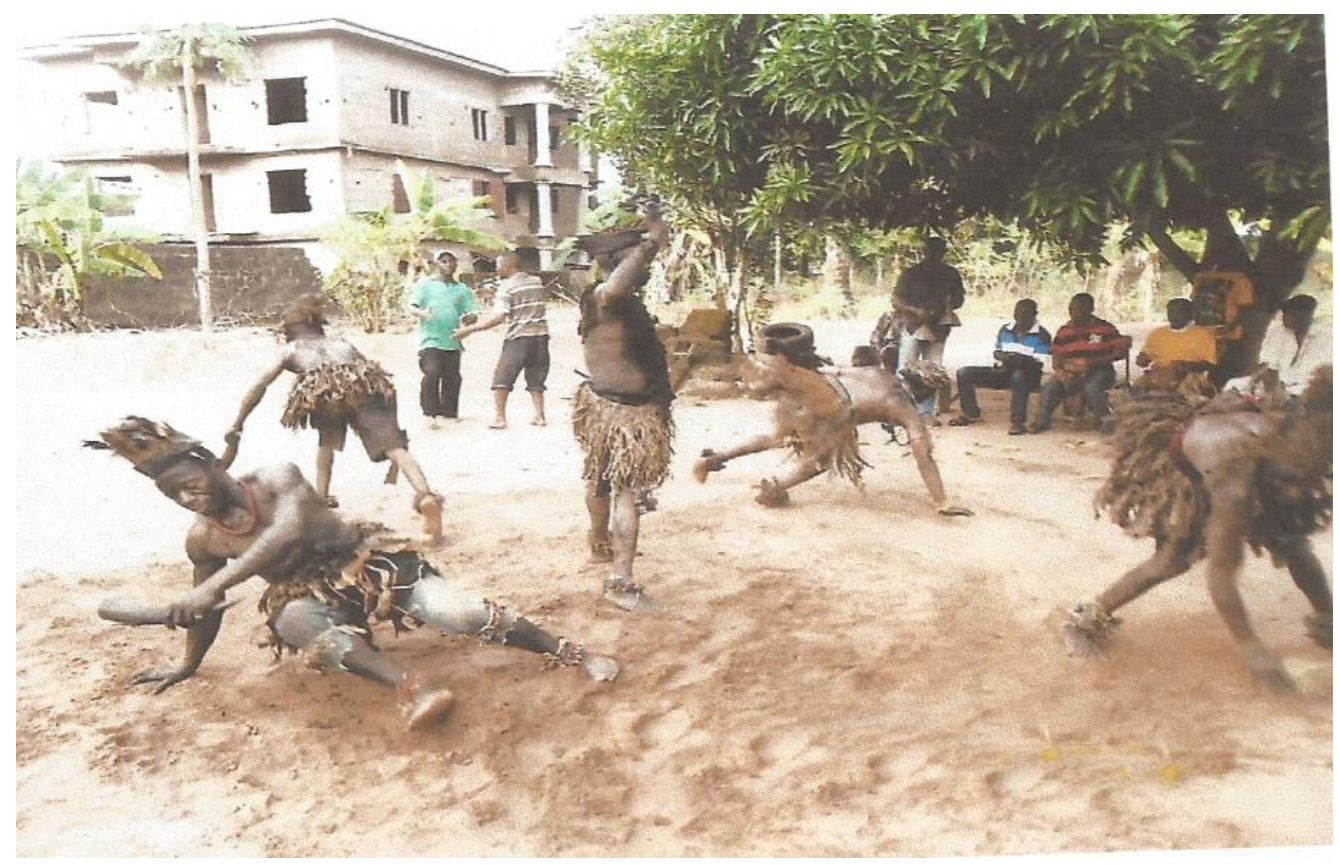

Plate 4: $I d u$ dancers in action

$I d u$ cultural dance ensemble is a stylized dance that has four categorized dance movements (obala egwu). The performance of the four dance movements in any function depends on the performance context. The duration of each of the four dance movements/segments is determined by the lead instrumentalist. The first movement is in a lively tempo introduced by the nne ekwe, master instrument followed by the okpokolo, the pulse maker which maintains a steady beat that regulates the tempo of other instruments. This segment and other segments are performed in a circular formation. Dancers adhere to the rhythmic pattern established by the instrumentalists. The segment is characterized by zig zag movement of the dancers while they still maintain the dance formation. The master instrumentalist introduces the second movement by playing a signal phrase that alerts other instrumentalists and the dancers of a change in movement. Onuorah - Oguno (2005) highlighted this fact when he opined that musical phrases, characteristics of different dance steps are played to cue the dancers.

The second segment begins in a moderate tempo. Here, the dancers in their circular form faces the center, stamp their feet to the ground moving rhythmically to the left and right. The tempo increases as the music progresses; with the increase in tempo, the dancers systematically and rhythmically sits on the ground with stretched legs making forward and backward movements with their buttocks. 


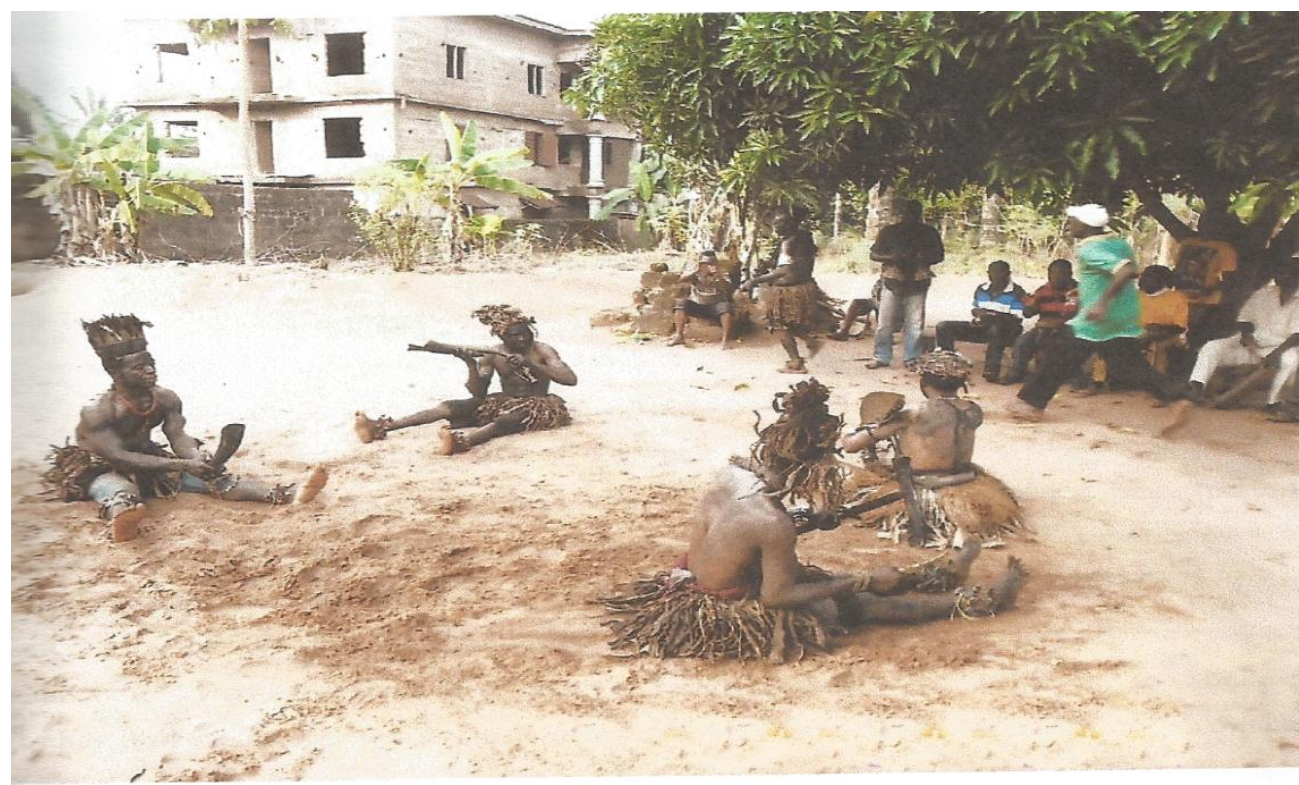

Plate 5: second movement of the dance.

The third segment is the climax of the dance. Dancers in fast tempo swing to the left, right and stamps their feet on the ground making a slight jump. At a point the dancers pull out their machetes and demonstrate their pride as warriors. The dancers go frenzy as they show off their creative abilities. The music spurs them to exhibit some unexpected actions like cutting down of branches of trees. Some climb the palm trees without the climbing rope to aid them. They are called to order with the melodic phrases played by the flutist, thus they return to the normal dance movement. This segment introduces 'ida iya', an act that determines how strong a man is, it also shows how one is valued by the people. Anyone with a questionable character is not applauded while men of noble characters are applauded and appreciated by spraying of money. 'ida iya' is not done by the dancers but by members who are not involved in the dancing and other members of the community.

The fourth segment of the dance is introduced by the master instrumentalists after 'ida iya'. This segment is also in a lively tempo and the same dance formation is maintained. The group retires with this movement in reverse order. The dancers leave the performance ground followed by the instrumentalists.

The performance of $I d u$ is not an annual event neither does the seasons of the year affect its performance as stated by Akas (2014) that:

The dance Iduu Akpo dance performance is an annual performance from a primodial era till present day in Akpo ... it is also good to note 
that this dance is not performed during rainy season, because rainy season is a period of farming and serious labour, while dry season, which is a period when the dance is being performed serves as a period of enjoyment and relaxation after harvesting the farm produce (p.198)

$I d u$ performs at functions on invitation. The invitation could be with or without the masquerade depending on the discretion of the group or host. Their performance style in any event depends on the context of the event. If they are invited to accompany their host to a condolence visit, they lead their host into the arena with music in a moderate tempo. The host and his friends take the lead followed by the instrumentalists and then the dancers. After presenting the condolence items, the group is given an opportunity to perform. Most times, during funeral ceremonies the group is not allowed to display all the four segments of their dance. There used to be lineup of sympathizers or in-laws waiting to be ushered in to perform their funeral rites. When such is the case, each group is given limited time to display what they have. Due to the nature of the dance, the group has never at any time performed in a hall, their performance has always been in an open space.

Audience participation is allowed in the performance of $I d u$. The audience show their excitement and appreciation by dancing/walking up to the dancers or instrumentalists to spray money on them. This appreciation is shown by both men and women except where masquerades are involved, the women will not move to the performance ground rather they throw their money from their where they were sitting or standing.

\section{Summary / Conclusion}

Every country in Africa has a duty to record, protect and preserve her history. African music carries information needed about life and event of a community. It traces the past consolidate the present and forecast the future (Ibekwe 2013: 128). Traditional music has been viewed as an indispensible part of and Igbo culture and Africa at large. It plays an important role in the life of Akpo people. Tradition music in Akpo encourages healthy relationship among the people. Membership into Idu accommodates young men from the age of thirty including very senior ones irrespective of their social status, and this establishes a kind of symbiotic relationship among the members. Dance music like most other African music types is performed as a social event. Idu cultural dance is among the most cherished dance music in Akpo that has survived over the years, despite the western influence on Igbo music. This research work reveals that $I d u$ dance has never at any time been performed in an enclosed building. The performance venue is typical of African music performance. The study debunked the wrong notions held by some scholars and individuals about the dance due to its costume and recommends that more studies on the group be conducted by the men folk beyond the limitation of the researcher. This is necessary because due to 
gender dichotomy, the researcher was denied some salient information in relation to the activities of the group's masquerade. Music scholars should always accept to serve as patrons and patronesses (nna egwu / nne egwu) to performance groups whenever they are approached with such requests, this will make for a better understanding and documentation of the group's activities.

\section{References}

Agu, D. C. C. (1990). The primacy of music in Igbo traditional religion, in Ekpunobi, E. \& Ezeaku, L. (eds.). Socio- philosophical perspective of African traditional religion. 49-55.

Agu, D. C. C. (2000). Music in the Nigeria culture: type and practices, in Orjiakor, N.E Unachukwu, G.C \& Obiajulu, A. (Eds.). Challenges of national youth growth and development in Nigeria. 79 -88. Enugu: John Jacobs classic publishers Ltd.

Agu, D. C. C. (2011a). Use of folk music as instructional material for moral and musical arts education in Igbo culture, Nigeria. Awka journals of research in music and arts (AJRMA). 8, 1-18.

Agu, D. C. C. (2011b). The impact of electronic music technology into on indigenous and pop music. The Nigerian experience. Journal of the Association of Nigerian Musicologists. 5, 16-22.

Agu, D. C. C. (2015). The application of individual knowledge system in music education and practice in Nigeria: A most valuable option. Journal of Nigerian Music Education. 7, 1-8.

Akas, N. C. (2014). Indigenous dance beyond movement: A semitonic metaphor of Idu Akpo dance performance. Awka Journals of Research in Music and Arts (AJRMA).10. (pp. 192-205).

Chuma-Udeh, N. (2014). Music in oral literature by Sephardic Jews and Igbos of western Nigeria: A comparative analysis. Awka journals of research in music and arts vol.10. (pp. 15-31).

Ekwueme, L. U. (2008). A basic guide to music appreciation. Lagos: Apex books.

Ezenwata, S. M. (2012). Who is who in Akpo? A reminiscent survey of Akpo, origin and growth in synopsis. Port Harcourt: PGI. Printing concepts

Forchu, I. I. (2012). Nigerian traditional music: An implementation for human development. Nsukka Journal of Musical Arts and Research.1, 208-219.

Forchu, I. I. (2011). Channeling traditional music to sustainable development. Journal of the Association of Nigerian Musicology. (JANIM). 5, 23 - 36. 
Ibekwe, E. U. (2013). The philosophy of African music as oral literature. Awka Journals of Research in Music and Arts. 9, 125-134.

Isaac, E. U. (2013). The role of a composer in national development: A case study of Okon Udo Udo. Journal of the Association of Nigerian Musicology. 7, 55 - 64.

Keke, M. T. O. \& Obiekwe, C. N. (2012). The integrity of traditional music in Nigerian society, Nsukka Journal of Music Arts and Research. 1, 303-311.

Nii-Yartey, F. (1989). Creation and presentation of Nigerian music dances, a review of basic Ghanaian attitudes. Africa, Quarterly. 29\# 1-2, 57-64.

Nketia, J. H. K. (1975). The music of Africa. New York: W.W. Norton

Nzewi M. \& Nzewi O. (2007). A contemporary study of musical arts informed by African indigenous knowledge systems. Volume 1 the Roots: Foundation. Ciimda

Odunuga, A. F. (2009). Introduction to the study music. Lagos: Right-time Service.

Okafor, R. C. (2005). Music in Nigerian society. Enugu: New Generation Books.

Okafor, R. C. \& Emeka, L. N. (2013). Nigerian people and culture. Enugu: New Generation Books.

Okafor, R. C. \& Okafor C. U. (2009). Music and National Development in Nigeria. Enugu: New Generation Books.

Okpala, H. N. (2006). Musical activities of children in Uga community of Aguata. L.G.A. M.A. thesis, Nnamdi Azikiwe University Awka

Olaniyan, Y. (2014). The concept and dimension of Yoruba variety of African music. Nigerian Music Reviews. 13, 1-11.

Onuora-Oguno, N. C. (2005). Ugwella-Egwu music: a study of aesthetic in African music. Interlink, A Journal of Research in Music. 2, 78-86.

Onwuka, U. A. (2012). A basic text for dance education on Nigeria. Eziowelle / Onitsha: Jenison

Onyeji, C. (2013). Barely dressed: A reflection on the aesthetic of female costuming for indigenous music performance in Batswana tribe of South Africa, Journal of the association of Nigerian musicology, 7, 56-75.

Onyekwelu, J. (2011). African organized dance. A case study of igba enyi-Nimo. Nimo: Rex Charlse and Patrick Ltd.

Ugolo, C. (2012). Dance forms in Nigeria: Issues of classification and theoretical concerns, Journal of the Association of Nigerian Musicologist. 6, 98-105. 